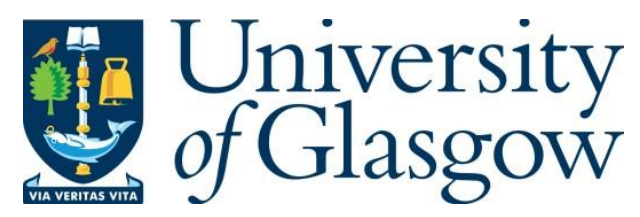

Creasy, M. (2019) William Empson, The Face of the Buddha. Style, 53(2), pp. 269-272 [Book Review].

There may be differences between this version and the published version. You are advised to consult the publisher's version if you wish to cite from it.

http://eprints.gla.ac.uk/191626/

Deposited on: 1 August 2019

Enlighten - Research publications by members of the University of Glasgow http://eprints.gla.ac.uk 
CT]William Empson. The Face of the Buddha. Edited by Rupert Arrowsmith, Oxford UP, 2016. pp. 1xii + 152. £30. 978-0-19-965967-8.

Some faces bear more scrutiny than others. In an early poem, "Letter," first published in 1928, William Empson compares the face of a loved one to a "cave gallery": in this metaphor, his gaze becomes a "torch," so that glimpses and insights into the face become "fresco after fresco," appearing and disappearing as the light catches different facets of the cave. Whilst Empson is "ravish[ed]" by what he finds, the act of bringing in the light also threatens to destroy the delicate cave paintings. The poem does_not hold out much hope for a relationship, then, since the speaker's interest is only sustained whilst he can find new things in the object of his love. An intense desire to pass beyond surface appearances is tempered by an awareness of human limits.

The idea of a facial expression or mood that shifts or appears to change according to lighting conditions is also found at the heart of a newly recovered work by Empson, The Face of the Buddha. Copiously illustrated with colour and black and white photographs, this offers a historical and geographical survey of statues, busts ${ }_{2}$ and monuments featuring the Buddha that Empson encountered during his travels in China and Japan before the Second World

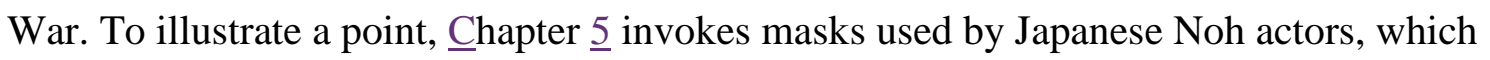
convey differing emotional states depending upon the angle from which they are viewed. A skilful actor is thus able to perform different moods using a static expression. Empson cites this practice as an example of an accepted phenomenon to prove his own more tenuous theory that statues of the Buddha deliberate incorporate asymmetry into their faces. Lacking written sources of confirmation, Empson builds up to this claim through multiple examples. Thus, he cites the "overhanging upper eyelids" of the colossal Buddha at Kamakura (83) and observes that an effect of shadow makes the eyes appear to open as suppliants approach to pray underneath it. Such quasi-theatrical tricks help to bring an immobile object to expressive life. As he concedes, these two examples come from different times and cultures, but they provide a clear precedent for his broader argument. For, one key effect of asymmetry, he claims, is that it serves as a means of "making a fixed face appear subtle and alive" (83).

A drunken misunderstanding between friends led Empson to believe that the manuscript for this project had been mislaid, left in the back of a taxi during 1947. Compounded by the untimely death of a potential editor, his assumption that the work was lost left it languishing in archives at the British Library until a chance discovery in 2005. It has now been lovingly restored and edited by Rupert Arrowsmith for Oxford University 
Press. Although the subject matter of this handsome volume is specialist, there is a strong resonance between The Face of the Buddha and Empson's better-known work as a poet and literary critic. The asymmetry theory was important to him because he saw it as a way of "combining things that seem incompatible" (81). This description clearly recalls his famous remark in a note to the poem "Bacchus" that "life involves maintaining oneself between contradictions that can't be solved by analysis.". A desire to engage with and untangle such complexities is a mainstay throughout his writings. Like the speaker of "Letter,", restlessly probing his lover's face for clues, Empson's close scrutiny of facial expressions in statues of the Buddha aims to bring them to life and recapture a similar liveliness of thought.

Unlike the Noh masks or the statues at Kamakura, this is not, however, a trick of the light: the intellectual life Empson discerns behind the apparent passivity of the Buddha is also something that his prose performs for the reader. One way he achieves this is through his style, which has a characteristic habit of modulating into less formal registers. Buddha, he suggests, might view an overzealous follower as "rather a busybody" (14); one Mathura Buddha conveys “a certain Boy Scout quality” (22) whereas the "high rounded eyebrows" of another make it look like "a Mabel Lucie Attwell baby" (15). There is a generous inclusivity in these looser moments, as if inviting the reader to relax into the task at hand, but this verbal strategy is risky too. Such lexical shifts might be thought to undo the apparent seriousness he brings to his inquiry, or they might seem arrogant, as though Empson felt himself superior and secure enough in his own self-worth not to have to maintain vigilance over technical or specialist vocabulary.

Likewise, his choice of allusions to popular culture, such as Attwell's pictures or the comedian George Robey (70) could seem suspect too. A hostile reading of Empson's book might detect an element of intellectual tourism here, as if he were too lazy to look further. The politics of citing Western phenomena to explain Chinese religious sculptures may seem dubious to some:

[QO]The Horiuji Buddha [...] is not straining his mouth when depicted; the run of the mouth comes from a habitual use of muscles, rather suggesting the 'convulsive inclination to risibility' which Hazlitt said spoilt the classic features of Wordsworth, and might be guessed on the portraits of Milton. Such a mouth perhaps sags inwards because the emotional life does not fill the space the intellect has prepared for it (77). [/QO] 
Such a passage might be construed as an attempt to diminish the cultural difference between his own experiences and the Chinese culture observed_- the implication being that the mechanism of a smile is universal to human beings, so that Hazlitt's observations can be applied equally to both the Buddha and Wordsworth.

Such constructions would, however, be unfair to a genuine interplay between familiar and unfamiliar throughout The Face of the Buddha. In these passages, Empson is actively attempting to understand something strange him_-to find a common point between East and West without losing sight of the strangeness which attracted him to this spectacle in the first place. The effect is also to draw out a comic strangeness in the apparently familiar too:

$[\mathrm{QO}] \mathrm{Then}$ again one of the terrifying movements of the dragon dances, regularly repeated, is the same as our Music Hall policeman's 'easing the crutch,' which is itself apparently a mark of 'comically goodhumoured physical strength' (79).[/QO]

This account of watching a performance by Japanese ritual dancers hints at a "terrifying" element in the supposedly familiar musical hall routine. The effect reverses the gaze of Western cultural anthropologists who seek to turn other cultures and societies into the object of dispassionate inquiry; Empson offers a glimpse of what a more familiar phenomenon would look like when subject to similar scrutiny. The reader is invited to see the language of gesture employed by the comedy policeman (“_easing the crutch”) as a type, too. Unlike the fickle lover in "Letter,"- who requires novelty to sustain his interest (“glancing, walk on”), Empson's inquiries into representations of the Buddha are suffused with an ethical intelligence about difference and other ways of being. His findings may not always convince, but this volume provides ample evidence of the wit and sensitivity which characterise Empson's intellectual curiosity.

\AUךMATTHEW CREASY $[\mathrm{AU}-\mathrm{AFF}]$ University of Glasgow

[BIO]Matthew Creasy is a Lecturer in English Literature at the University of Glasgow. His critical edition of Arthur Symons' The Symbolist Movement in Literature was published by Fyfield-Carcanet in 2014. He has written articles and essays on the work of James Joyce, Arthur Symons, William Empson, and Villiers de l'Isle-Adam. He is currently leading an AHRC-funded network entitled "Decadence and Translation."

\section{[RFH]WORKS CITED}

[REFS]Empson, William. The Complete Poems. Edited by John Haffenden ${ }_{2}$ Penguin, 2000. 